\title{
Animal Investigation Program (AIP) A.I.P. Summary Report On and Around The Nevada Test Site From $1982-1995$
}

\author{
by \\ Kenneth R. Giles \\ The photos on the front and back cover were copied from \\ Widlife Management Techniques Manual \\ Prepared for the U.S. Department of Energy \\ under Interagency Agreement \\ DE-A108-91 NV 10963
}

RADIATION AND INDOOR ENVIRONMENTS NATIONAL LABORATORY

OFFICE OF RADIATION AND INDOOR AIR

U.S. ENVIRONMENTAL PROTECTION AGENCY

P.O. BOX 98517

LAS VEGAS, NV 89193-8517

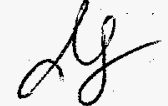

DISTRIBUTION OF THIS DOCUMENT IS UNLIMITED 


\section{NOTICE}

The information in this document has been funded wholly or in part by the United States Environmental Protection Agency (EPA) through Interagency Agreement DE-A108-91NV 10963 from the United States Department of Energy (DOE). It has been subject to the Agency's peer and administrative review, and it has been approved for publication as an EPA document. Mention of trade names or commercial products does not constitute endorsement or recommendation for use. 


\section{DISCLAIMER}

This report was prepared as an account of work sponsored by an agency of the United States Government. Neither the United States Government nor any agency thereof, nor any of their employees, make any warranty, express or implied, or assumes any legal liability or responsibility for the accuracy, completeness, or usefulness of any information, apparatus, product, or process disclosed, or represents that its use would not infringe privately owned rights. Reference herein to any specific commercial product, process, or service by trade name, trademark, manufacturer, or otherwise does not necessarily constitute or imply its endorsement, recommendation, or favoring by the United States Government or any agency thereof. The views and opinions of authors expressed herein do not necessarily state or reflect those of the United States Government or any agency thereof. 


\section{DISCLAmIER}

Portions of this document may be illegible in electronic image products. Images are produced from the best available original document. 


\begin{abstract}
This report describes the Animal Investigation Program conducted from 1982 - 1995 by the Environmental Protection Agency's (EPA's), Radiation and Indoor Environments National Laboratory (R\&IE), formerly Radiation Sciences Laboratory-Las Vegas. This laboratory operates an environmental radiation monitoring program in the region surrounding the Nevada Test Site. The surveillance program was designed to measure levels and trends of radionuclides in animals on and around the Nevada Test Site to ascertain whether world-wide fallout, current radiation levels, and associated doses, to the general public were in compliance with existing radiation protection standards. The surveillance program additionally had the responsibility to take action to protect the health and well-being of the public in the event of any accidental release of radioactive contaminants.

Comparison of the measurements and sample analysis results indicated that no significant amounts of biological radionuclides had been detected in the near offsite areas or on the NTS, except in animals drinking water that drains from tunnels in Area 12.
\end{abstract}


This page left blank intentionlly 
Table of Contents

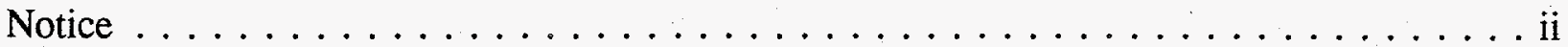

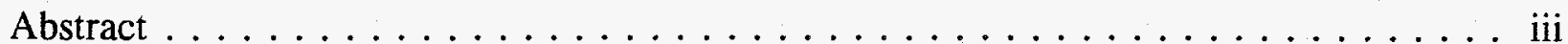

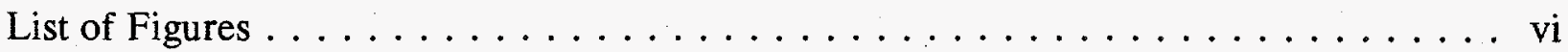

Abbreviations and Acronyms $\ldots \ldots \ldots \ldots \ldots \ldots \ldots \ldots \ldots \ldots \ldots \ldots \ldots$

Acknowledgments $\ldots \ldots \ldots \ldots \ldots \ldots \ldots \ldots \ldots \ldots \ldots \ldots \ldots \ldots \ldots \ldots$

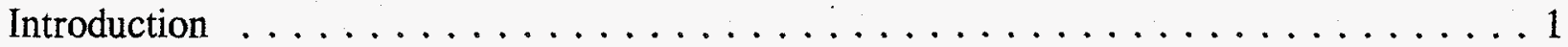

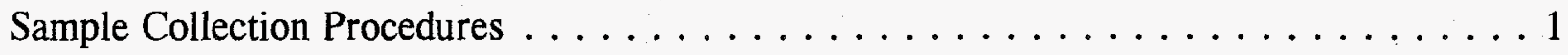

Quality Assurance/Quality Control . . . . . . . . . . . . . . . . 4

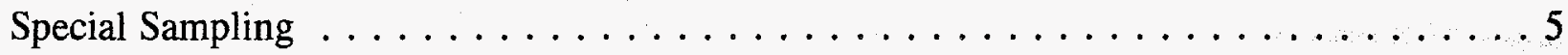

Histopathology $\ldots \ldots \ldots \ldots \ldots \ldots \ldots \ldots \ldots \ldots \ldots \ldots \ldots \ldots \ldots \ldots \ldots \ldots \ldots \ldots \ldots \ldots$

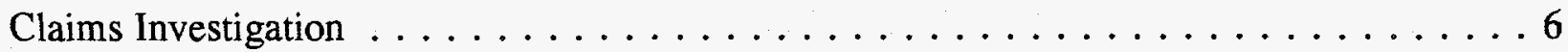

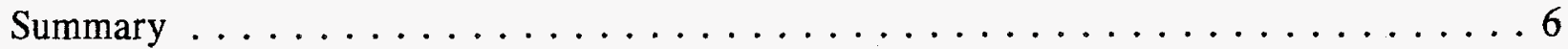

References $\ldots \ldots \ldots \ldots \ldots \ldots \ldots \ldots \ldots \ldots \ldots \ldots \ldots \ldots \ldots \ldots \ldots \ldots$

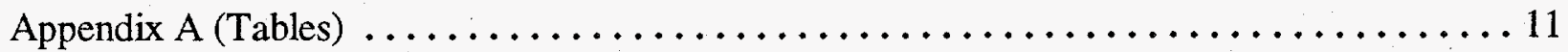

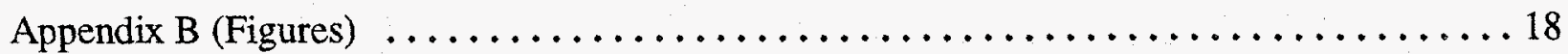

Appendix C (Announced U.S. Nuclear Tests) $\ldots \ldots \ldots \ldots \ldots \ldots \ldots \ldots \ldots \ldots \ldots$ 


\section{List of Figures}

1. Locations of summer and winter collection of mule deer $\ldots \ldots \ldots \ldots \ldots \ldots \ldots \ldots$

2. Total number of bighorn sheep collected during annual hunt from $1981-1992 \ldots \ldots \ldots \ldots$

3. Locations of cattle sampled near the NTS ..................... 


\section{Abreviations and Acronyms}

$\begin{array}{lll}\text { ACE } & - & \text { U.S. Atomic Energy Commission } \\ \text { AIP } & - & \text { Animal Investigation Program } \\ \text { EMSL-LV } & - & \text { Environmental Monitoring Systems Laboratory-Las Vegas } \\ \text { EPA } & - & \text { U.S. Environmental Protection Agency } \\ \text { MDC } & - & \text { minimum detectable concentration } \\ \text { NTS } & - & \text { Nevada Test Site } \\ \text { QA } & - & \text { quality assurance } \\ \text { QC } & - & \text { quality control } \\ \text { R\&IE } & - & \text { Radiation and Indoor Environments National Laboratory }\end{array}$




\section{Acknowledgments}

The external peer reviews were provided by D.D. Smith, D.V. M., USPHS retired, of Las Vegas, Nevada, and Mr. R.A. Brechbill, DOE retired, of Wibaux, Montana. The contributions of these reviewers in production of this final report are gratefully acknowledged.

The author would like to thank Anita A. Mullen and Colleen F. Petullo for their advice and assistance in the preparation of this report. The author would like to extend his appreciation to Christopher A. Fontana for his technical assistance, Rose-Marie Chelhot for her computer graphics, and to Angela B. Haag for literature research. The author would like to thank Terry L. Mouck for her skill and dedication in word processing and desktop publishing support which was crucial to the production of this report. 


\section{Introduction}

In November 1955, the U.S. Atomic Energy Commission (AEC) established a program to investigate claims of injury to domestic animals alleged to be caused by nuclear tests at the Nevada Proving Grounds. The Nevada Proving Grounds was renamed the Nevada Test Site (NTS) and the original program was expanded to develop the Animal Investigation Program (AIP).

The AIP began in 1957 (Ref. BER-6) with the purchase of a herd of beef cattle which were allowed to graze on the NTS. This herd was maintained on the NTS until 1981. In the fall of 1981 the herd was rounded up and transferred to the University of Nevada in Reno, Nevada. This terminated a 25 -year study of a single herd which had lived in an area contaminated by nuclear testing activities. The animal-sampling portion of the AIP was continued through 1995 with the semiannual sampling from commercial beef herds, quarterly sampling of the NTS deer herd, annual sampling of the bighorn sheep, and annual sampling of food crops grown on farms and ranches adjacent to the NTS. Veterinarian services was provided by the U.S. Army from 1955 to 1964 until being assigned to the U.S. Public Health Service. The U.S. Public Health Service provided veterinarian services until the program was terminated in 1995.

\section{Sample Collection Procedures}

Beginning in 1982 cattle were purchased from the ranchers that lived in close proximity to the Nevada Test Site (NTS). Each spring and fall, four beef animals were selected that lived in open range areas for most of their lives. These animals were transported by the Environmental Protection Agency from the Farm Facility to Area 15, where they were necropsied.

Each necropsied animal was sampled for radionuclides in muscle, lung, liver, bone, blood, kidney, thyroid and fetus if available. Each animal was also given an examination for gross pathological condition. Samples for histopathology studies included adrenal glands, eye, heart, kidney, lung, muscle, liver, spleen, gonads, thyroids, and any gross lesions found.

Mule deer (Odocoileus hemionus) were collected on a quarterly basis on the NTS. They were generally collected in the Pahute Mesa, Rainier Mesa area in the summer and from the areas on the south of these mesas in the winter. For locations, see Figure 1 (for past migration patterns Ref. EPA 600/4-85-030). The same type samples were taken on the mule deer and the same analysis performed as on the cattle. During 1993 - 1994 one mule deer a year was collected offsite in Nye County near Adaven, NV to be used as a control.

Bighorn sheep were collected by licensed hunters with the cooperation of the Nevada Department of Wildlife. For locations, see Figure 2. Sample kits were provided to hunters during

annual hunter indoctrination classes. Hunters were asked to provide age, location, and date of the kill. Also, they were asked to provide hock bone and kidneys for radionuclide analysis. Bighorn sheep sampling was discontinued in 1993 due to lack of hunter response and budgetary constraints. 


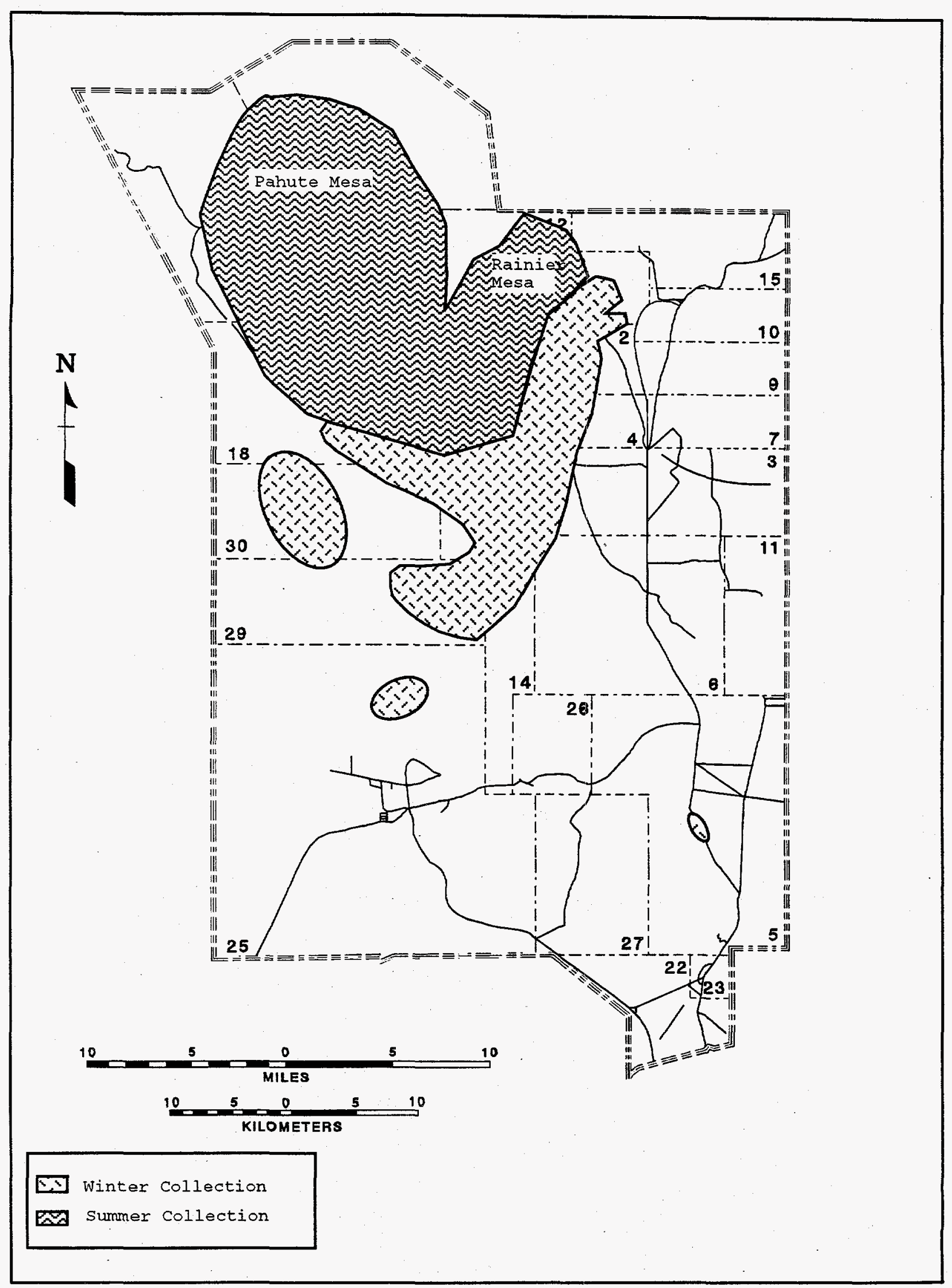

Figure 1 Locations of summer and winter collection of mule deer. 


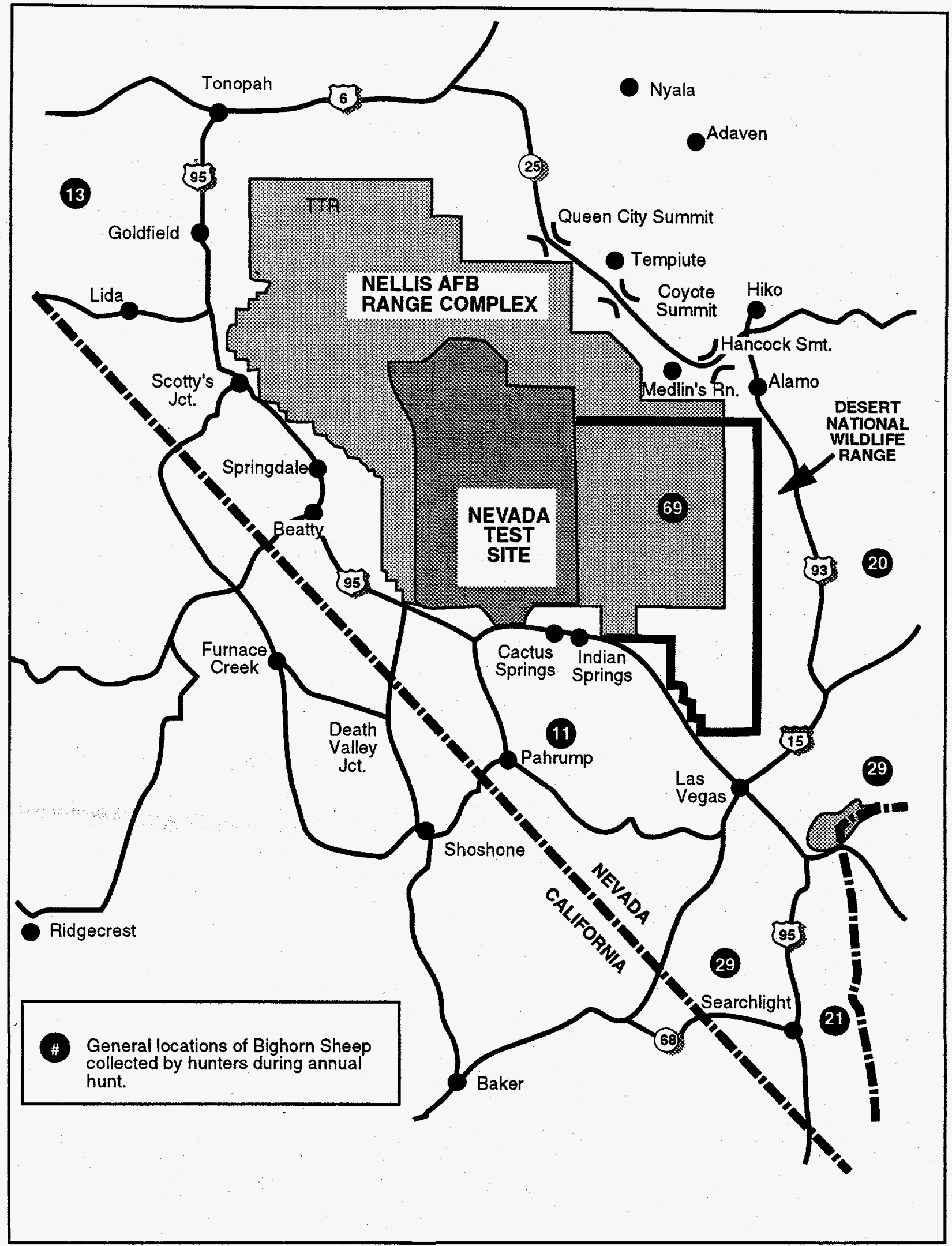

Figure 2 Total number of bighorn sheep collected during annual hunt from 1981 - 1992. 


\section{Quality Assurance/Quality Control (QA/QC)}

Standard operating procedures detailed sample collection, preparation, storage, analysis, and data review procedures to ensure comparability among operators. Field personnel completed a standardized necropsy protocol form to ensure that all relevant information was recorded, such as date and location of collection, history and condition of the animals and tissues, sample weights, and assigned identification numbers. Standardized forms accompanied each shipment of samples sent to the contract laboratory for ashing and were also used for analyses conducted in the Radioanalysis Laboratory. All information entered into the data base management system by Sample Control and the radioanalysis chemists were checked and verified for analytical precision and accuracy by the Group Leader and assigned media expert.

An estimate of system precision was obtained from results of duplicate samples. Matrix spike samples were used to verify analytical accuracy. Matrix blank samples monitored any contamination resulting from sample preparation and analysis. The entire sample set analyzed in any given year was quite small (usually four or five sample batches) and, consequently, the QA/QC sample result set contained fewer values than was considered minimal for statistical uses. Therefore, the results of QA/QC samples were considered to provide only an indication or estimate of true precision and accuracy. This was considered adequate because the Animal Investigation Program itself was not statistically based.

Before 1991, analyses of animal tissue samples were performed by a contract laboratory. The EPA Environmental Monitoring Systems Laboratory-LV, Radioanalysis Branch assumed responsibility for sample analysis beginning with the results contained in this report. The change of laboratories raised concerns about comparability of analyses, so a special QA review was conducted. The procedures used by each laboratory were comparable, as were results of matrix spike samples. Generally, the result ranges obtained in 1991 were similar to those obtained in previous years when samples were analyzed by the contract laboratory. Finally, results of QAVQC samples, with the exception of one routine duplicate pair, were within established control limits. Although a direct comparability study was not undertaken (i.e., analysis of replicate samples by both laboratories), the results of the QA review indicated the data obtained for 1992 analyses were comparable to data obtained in previous years (EPA 1990, EPA 1991, and EPA 1992).

The QA review also resulted in recommendations for some changes in the animal investigation program that were implemented in 1992. These recommendations included preparation of a large stock of matrix spike and blank sample material and addition of a system blank. The single stock of matrix spike sample material permited an additional estimate of precision, in this case analytical precision, to be obtained. The system blank was a bone sample known to contain no detectable concentrations of radionuclides (with the possible exception of strontium). It was processed with each tissue sample batch to provide a check of possible contamination during the ashing and sample preparation processes. 


\section{Special Sampling}

Following the Mighty Oak Test (April 1986), mule deer were collected that had been drinking water draining from the T-tunnel complex in Area 12 on the NTS. A total of three deer were collected (on June 17, September 9, and October 23, 1986). A wide variety of fresh fission products $\left({ }^{131} \mathrm{I},{ }^{103} \mathrm{Ru},{ }^{106} \mathrm{Ru},{ }^{95} \mathrm{Zr},{ }^{3} \mathrm{H}\right.$ and $\left.{ }^{89} \mathrm{Sr}\right)$ were detected in the soft tissue and ingesta samples. Iodine-131 was still detectable in the thyroid of deer collected on September 9, 1986, 152 days after the nuclear detonation. The results are shown in Appendix A. Appendix C lists the Announced United States Nuclear Tests conducted at the NTS during the period covered by this report.

During June 1987, one horse was sampled in Area 18 at the NTS. This animal had an ocular squama cell carcinoma that involved the entire left side of the head. Muscle and bone samples were taken for radioanalysis. Only naturally occurring ${ }^{40} \mathrm{~K}$ was detected in the muscle. Radionuclide concentrations of ${ }^{239+240} \mathrm{Pu}$ in ashed bone were $0.013 \pm 0.005 \mathrm{pCi} / \mathrm{g}$ ash and radionuclide concentrations of ${ }^{90} \mathrm{Sr}$ in ashed bone were $5.0 \pm 0.17 \mathrm{pCi} / \mathrm{g}$ ash.

A female mountain lion (Felis concolor) that had been menacing Area 12 personnel on the NTS was killed by an authorized NTS hunter in the spring of 1991 . The lion was in extremely poor physical condition. The animal appeared to have been starved into a very weakened condition. The necropsy revealed no injury or physical problems. Gamma analyses were performed on samples taken from the mountain lion's kidney, lung, muscle, blood, and liver. The analyses on these samples found only naturally occurring ${ }^{40} \mathrm{~K}$. Tritium analysis on the animal's blood resulted in $71,300 \pm 400 \mathrm{pCi} / \mathrm{L}$ - indicating she drank from the Area 12 ponds. Plutonium and Strontium analyses were performed on ashed bone samples. Muscle and bone samples were ashed and analyzed for plutonium isotopes; the bone sample was also analyzed for ${ }^{90} \mathrm{Sr}$ in bone, with a result of $1.09 \pm 0.07 \mathrm{pCi} / \mathrm{g}$ ash, and ${ }^{239+240} \mathrm{Pu}$ in muscle, with a result of $0.018 \pm 0.009 \mathrm{pCi} / \mathrm{g}$ ash. For mountain lion sighting see Appendix B, Figure 1.

During the summer of 1993, a request was made by the Nevada Department of Wildlife personnel to trap chukar (Alectoris chukar) on the NTS. Several chukar's were collected in areas adjacent to T-tunnel, Tub Spring, Tippipah Spring and Tonopah Spring. In addition, one quail was collected at White Rock Spring. Gamma, tritium and plutonium and strontium analyses were performed on the chukars. The gamma analyses found naturally occurring ${ }^{40} \mathrm{~K}$ and ${ }^{137} \mathrm{Cs}$. The ${ }^{137} \mathrm{Cs}$ was found in the Tippipah Spring chukar(s) at $0.030 \pm 0.009 \mathrm{pCi} / \mathrm{g}$ and in the Tub Spring chukar(s) at $0.19 \pm 0.02 \mathrm{pCi} / \mathrm{g}$. Tritium was detected in chukar samples collected near T-tunnel and Tub Spring. Tritium results ranged from 0.61 to $38,700 \mathrm{pCi} / \mathrm{L}$ in internal organs and 1.33 to $32,800 \mathrm{pCi} / \mathrm{L}$ in muscle. Plutonium and strontium analyses were performed on bone samples of three of the chukars collected at Tippipah Spring. The ${ }^{239+240} \mathrm{Pu}$ results on these bone samples ranged from 8.7 to $490 \mathrm{pCi} / \mathrm{g}$ ashed bone and the ${ }^{90} \mathrm{Sr}$ results ranged from 0.24 to $3.5 \mathrm{pCi} / \mathrm{g}$ ashed bone.

In 1994, two chukars were collected in Esmeralda County by Nevada Department of Wildlife personnel. The chukar were used as controls for the NTS chukar sampling. Only naturally occurring ${ }^{40} \mathrm{~K}$ was found in the muscle. No tritium was detected in the muscle above the MDC 
$\left(450 \times 10^{-4} \mathrm{pCi} / \mathrm{mL}\right)$. No strontium was found in the bone ash above the MDC $\left({ }^{89} \mathrm{Sr} .25 \mathrm{pCi} / \mathrm{g}\right.$ and $\left.{ }^{90} \mathrm{Sr} .37 \mathrm{pCi} / \mathrm{g}\right)$. The one bone sample with plutonium slightly above the MDC $\left({ }^{238,239,240} \mathrm{Pu} .008\right.$ $.02 \mathrm{pCi} / \mathrm{g}$ ) was $3.5 \mathrm{pCi} / \mathrm{g}$ ash of ${ }^{239+240} \mathrm{Pu}$. See Appendix A Table 3, for ${ }^{90} \mathrm{Sr}$ concentrations for miscellaneous wildlife on the NTS.

During the summer of 1994, an aged Hereford bull was killed in Area 18. This was the last surviving animal from the original NTS beef herd and had spent his entire life on the NTS (14 plus-years). This animal had a squamous cell carcinoma that had spread to both his kidneys and lungs. Only naturally occurring ${ }^{40} \mathrm{~K}$ was detected in soft tissue samples. Some ${ }^{239+240} \mathrm{Pu}$ was detected in the liver, lungs, rumen content, and bone which ranged from $0.018 \pm 0.06 \mathrm{pCi} / \mathrm{g}$ ash with the median of $0.023 \mathrm{pCi} / \mathrm{g}$ ash. The bone contained $1.42 \pm 0.446 \mathrm{pCi} / \mathrm{g}$ of ${ }^{90} \mathrm{Sr}$ per gram ashed and $0.019 \pm 0.007 \mathrm{pCi} / \mathrm{g}$ of ${ }^{238} \mathrm{Pu}$ per gram of rumen content ash.

\section{Histopathology}

From 1981 through 1995 all beef animals and mule deer were necropsied and tissue samples were collected. Histopathology revealed no significant lesions in the mule deer tissue on the NTS. In addition, there were only an occasional ocular squamous cell carcinoma found in beef cattle tissue. This squamous cell carcinoma is commonly found in cattle breeds with white hair and poorly pigmented skin around the mucous membranes of the eye (Ref. Merck vet. Manual 7th Edition).

\section{Claims Investigation}

The history of the Animal Investigation Program (AIP) has been well documented (Ref. Smith, Black 1957 - 1981). From 1981 - 1996 the AIP received no requests for investigation of alleged damage to domestic or wild animals in the NTS area.

\section{Summary}

During the 14-year period covered in this report the AIP sampled various commercial beef herds, mule deer, and bighorn sheep, that existed adjacent to the NTS (see Figure 3).

Out of a possible 388 soft tissue samples from cattle lung, liver, muscle, and rumen content, only 14 samples were above the MDC of $1.27 \pm 10^{-2} \mathrm{pCi} / \mathrm{g}$ for ${ }^{137} \mathrm{Cs}$. The samples ranged from 14.0 to $30 \mathrm{pCi} / \mathrm{g}$ wet weight. The results from mule deer were in the same range as the beef cattle for ${ }^{137} \mathrm{Cs}$ with the exception of animals collected near T-tunnel in Area 12. Radionuclide values for these animals are shown in Appendix A.

Cesium-137 was found in the kidney samples of bighorn sheep. Of the 195 samples collected, five had values greater than $\mathrm{MDC}\left(1.27 \pm 10^{-2} \mathrm{pCi} / \mathrm{g}\right)$, ranging from $23 \mathrm{pCi} / \mathrm{g}$ to 97 $\mathrm{pCi} / \mathrm{g}$ wet weight. A special effort was made to sample mule deer around T-tunnel in Area 12. The results of that sampling are shown in Appendix A. 


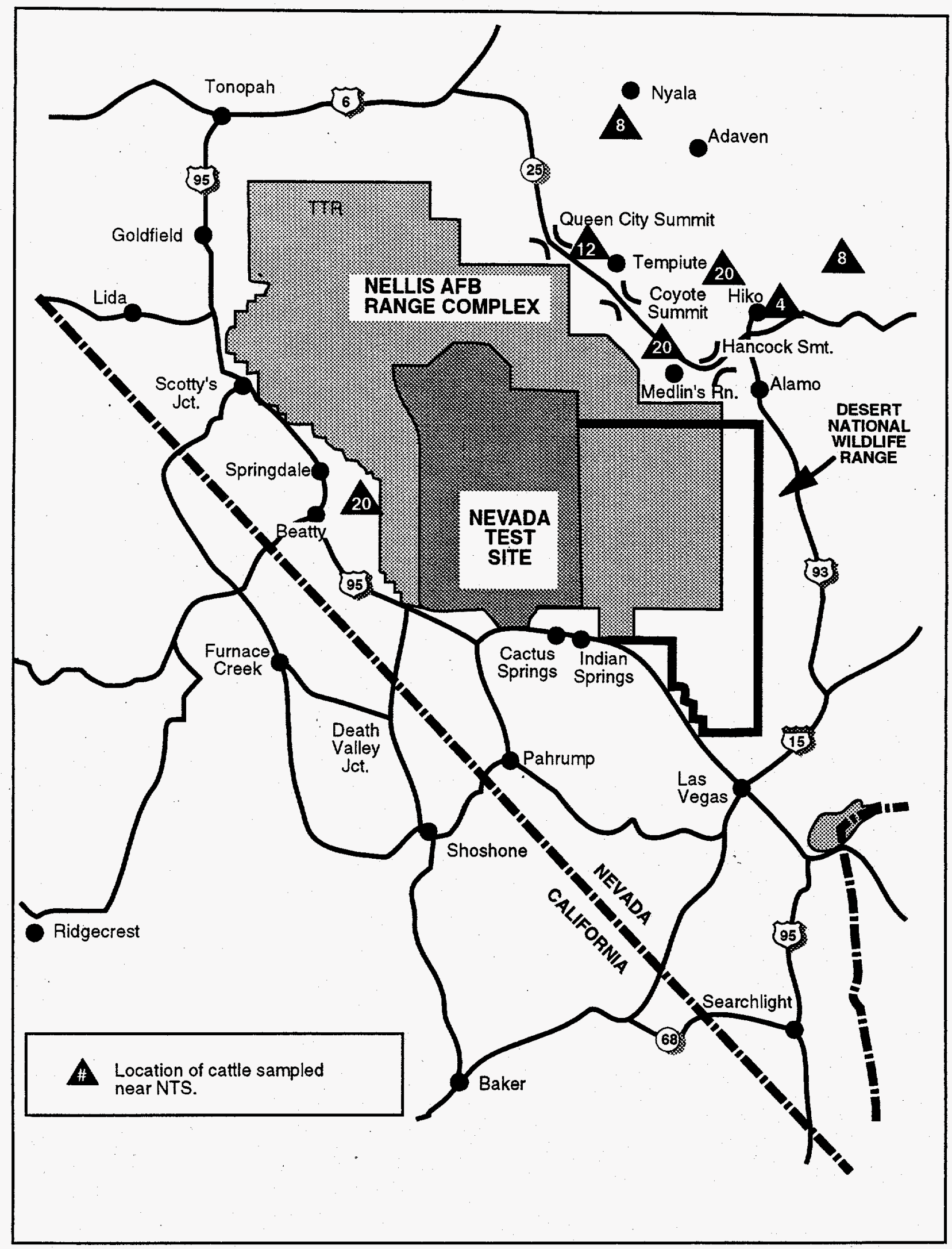

Figure 3 Locations of cattle sampled near the NTS. 
Strontium-90 in bone ash of all species sampled follows a similar decline, and levels appear to follow worldwide fallout; results are shown in Appendix A. The graphs in Appendix B shows the decline in ${ }^{90} \mathrm{Sr}$ from 1963 to 1995.

Tritium concentration in beef cattle and wildlife were within the range present in the general environment. Mule deer and chukar exposed to specific sources of tritium, (e.g., the ponds near T-tunnel in Area 12) had elevated concentrations as expected. See Appendix B, Figure 5 for tritium levels in mule deer.

Iodine-131 was detected in four beef cattle from the Rachel, Nevada area following the Chernobyl accident and thought to be associated with worldwide fallout from the accident. Iodine- 131 concentrations in the thyroid ranged from 1.5 to $27 \mathrm{pCi} / \mathrm{g}$. Iodine- 131 was detected in the thyroid of mule deer collected at $\mathrm{T}$ - tunnel during 1989 and their concentrations ranged from 12 to $2.0 \times 10^{6} \mathrm{pCi} / \mathrm{g}$.

Several ad hoc studies were conducted at the NTS, e.g., horse, chukar, and mountain lion sampling. The surveillance conducted at the NTS since 1982 suggested no significant amounts of radionuclides in biota have been detected in the near offsite areas or on the NTS except in animals drinking water from ponds near Area 12 tunnels. 


\section{References}

S.C. Black, R.F. Grossman, A.A. Mullen, G.D. Potter, and D.D. Smith, 1982. Offsite Environmental Monitoring Report: Radiation Monitoring Around United States Nuclear Test Areas, Calendar Year 1982, EPA-600/4-83-083. U.S. Environmental Protection Agency, Las Vegas, NV.

R.G. Patzer, C.A. Fontana, R.F. Grossman, S.C. Black, R.E. Dye, D.D. Smith, D.J. Thomé, and A.A. Mullen, 1986. Offsite Environmental Monitoring Report: Radiation Monitoring Around United States Nuclear Test Areas, Calendar Year 1986, EPA/600/4-87/017. U.S. Environmental Protection Agency, Las Vegas, NV.

C.A. Fontana, N.R. Sunderland, S.C. Black, B.B. Dicey, A.N. Jarvis, D.D. Smith, D.J. Thomé, and A.A. Mullen, 1987. Offsite Environmental Monitoring Report: Radiation Monitoring Around United States Nuclear Test Areas, Calendar Year 1987, EPA/600/4-88/021. U.S. Environmental Protection Agency, Las Vegas, NV.

C.A. Fontana, N.R. Sunderland, S.C. Black, B.B. Dicey, A.N. Jarvis, K.S. Moroney, A.A. Mullen, V.E. Niemann, D.D. Smith and E.A. Thompson, 1988. Offsite Environmental Monitoring Report: Radiation Monitoring Around United States Nuclear Test Areas, Calendar Year 1988, EPA/600/4-89/019. U.S. Environmental Protection Agency, Las Vegas, NV.

C.F. Costa, C.A. Fontana, N.R. Sunderland, S.C. Black, M.W. Chilton, B.B. Dicey, W.G. Phillips, R.W. Holloway, C.K. Liu, A.A. Mullen, V.E. Niemann, C.J. Rizzardi, D.J. Thomé, D.D. Smith and E.A. Thompson, 1989. Offsite Environmental Monitoring Report: Radiation Monitoring Around United States Nuclear Test Areas, Calendar Year 1989, EPA/600/4-90/016. U.S. Environmental Protection Agency, Las Vegas, NV.

C.F. Costa, N.R. Sunderland, S.C. Black, M.W. Chilton, B.B. Dicey, W.G. Phillips, C.A. Fontana, R.W. Holloway, C.K. Liu, A.A. Mullen, V.E. Niemann, C.J. Rizzardi, D.D. Smith, D.J. Thomé, E.A. Thompson, 1990. Offsite Environmental Monitoring Report: Radiation Monitoring Around United States Nuclear Test Areas, Calendar Year 1989, EPA/600/4-90/016. U.S. Environmental Protection Agency, Las Vegas, NV.

D.J. Chaloud, B.B. Dicey, A.A. Mullen, D.G. Easterly, C.A. Fontana, R.W. Holloway, W.G. Phillips, V.E. Niemann, D.D. Smith, N.R. Sunderland, and D.J. Thomé . Offsite Environmental Monitoring Report: Radiation Monitoring Around United States Nuclear Test Areas, Calendar Year 1990, EPA 600/4-91/030. U.S. Environmental Protection Agency, Las Vegas, NV.

D.J. Chaloud, B.B. Dicey, A.A. Mullen, A.C. Neale, A.R. Sparks, C.A. Fontana, L.D. Carroll, W.G. Phillips, D.D. Smith, and D.J. Thomé . Offsite Environmental Monitoring Report: Radiation Monitoring Around United States Nuclear Test Areas, Calendar Year 1991, EPA 600/R-93/141. U.S. Environmental Protection Agency, Las Vegas, NV. 
D.J. Chaloud, A.A. Mullen, A.C. Neale, C.A. Fontana, L.D. Carroll, D.M. Daigler, D.J. Thomé and M.G. Davis. Offsite Environmental Monitoring Report: Radiation Monitoring Around United States Nuclear Test Areas, Calendar Year 1992, EPA 600/R-94/209. U.S. Environmental Protection Agency, Las Vegas, NV.

D.J. Chaloud, D.M. Daigler, M.G. Davis, A.A. Mullen, A.C. Neale, B.B. Dicey, C.A. Fontana, S.H. Faller, K.R. Giles, P.A. Huff, F.Novielli and M.D. Sells . Offsite Environmental Monitoring Report: Radiation Monitoring Around United States Nuclear Test Areas, Calendar Year 1993, EPA 402-R-96-007. U.S. Environmental Protection Agency, Las Vegas, NV (In print).

K.R. Giles and J. Cooper. Characteristics and Migration Patterns of Mule Deer on the Nevada Test Site, EPA 600/4-85-030.

U.S. Department of Energy, Nevada Operations Office, Annual Site Environmental Report 1994, DOE/NV/11432-175. U.S. Department of Energy, Washington, D.C.

U.S. Department of Energy, Nevada Operations Office, Annual Site Environmental Report 1994, DOE/NV/11432-175. U.S. Department of Energy, Washington, D.C. (In Draft)

The Merck Veterinary Manual 7th Edition, 1991. Merck \& Co., Inc., Rahway, N.J., U.S.A. 1991.

Radiation Surveillance in Wildlife, 1967 (BER-6). Ronald E. Engel and Raymond A. Brechbill. 


\section{Appendix A}

Table 1. Radionuclide concentration from Mule Deer collected at T-tunnel.

Table 2. Nevada Test Site Mule Deer (Strontium-90 Concentration in Hock Bones)

Table 3. Nevada Test Site Miscellaneous Wildlife (Strontium-90 Concentration in Bones)

Table 4. Nevada Test Site Bighorn Sheep (Strontium-90 Concentration in Hock Bones)

Table 5. Nevada Test Site Beef Cattle (Strontium-90 Concentration in Femur Bones) 
Table 1. Radionuclide concentration from Mule Deer collected at T-tunnel.

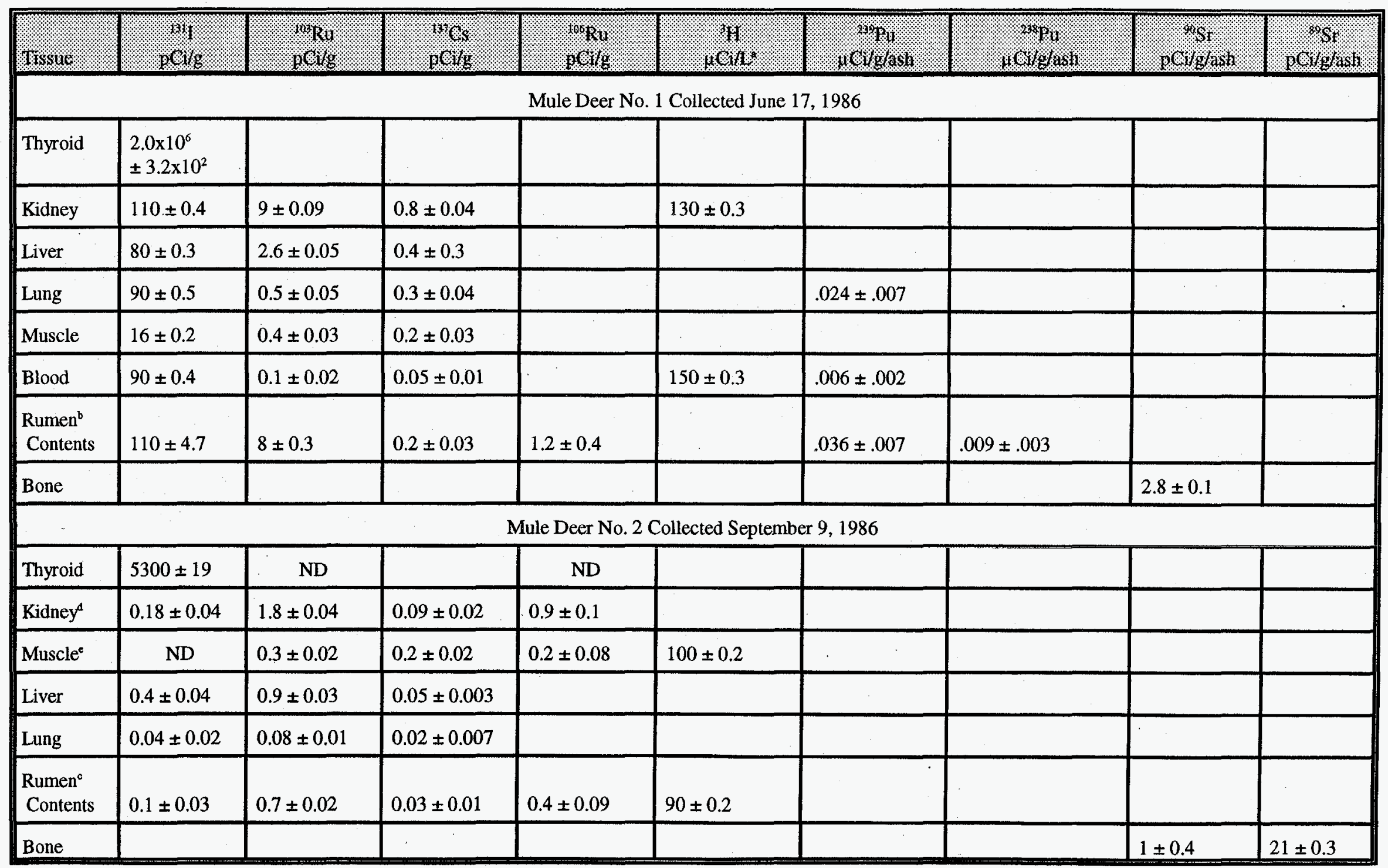

Note: All data in the tables are reported in 2 sigma data. 
Table 1. Radionuclide concentration from Mule Deer collected at T-tunnel (Cont'd)

\begin{tabular}{|c|c|c|c|c|c|c|c|c|c|}
\hline 145818 & 1. & 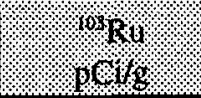 & $1 \%$ pos & 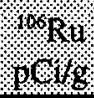 & 1141 & 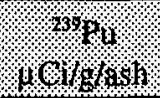 & 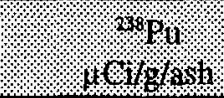 & 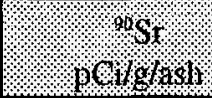 & \%o, \\
\hline \multicolumn{10}{|c|}{ Mule Deer No. 3 Collected October 23, 1986} \\
\hline Thyroid & \multicolumn{3}{|c|}{. } & & \multicolumn{3}{|c|}{ Gamma Spectrum Negligible } & & \\
\hline Kidney & \multicolumn{3}{|c|}{ Gamma Spectrum Negligible } & & $0.0009 \pm 0.00$ & & & & - \\
\hline Liver & \multicolumn{9}{|c|}{ Gamma Spectrum Negligible } \\
\hline Lung & \multicolumn{9}{|c|}{ Gamma Spectrum Negligible } \\
\hline Muscle & \multicolumn{9}{|c|}{ Gamma Spectrum Negligible } \\
\hline Blood & \multicolumn{9}{|c|}{ Gamma Spectrum Negligible } \\
\hline $\begin{array}{l}\text { Rumen }^{\mathbf{b}} \\
\text { Contents }\end{array}$ & \multicolumn{9}{|c|}{ Gamma Spectrum Negligible } \\
\hline Bone & & & & & & & $.0055 \pm .004$ & $.006 \pm .001$ & \\
\hline \multicolumn{10}{|c|}{ Mule Deer No. 4 Collected October 29, 1986} \\
\hline Thyroid & $12 \pm 1$ & & & & & & & & \\
\hline Kidneyd & \multicolumn{9}{|c|}{ Gamma Spectrum Negligible } \\
\hline Muscle $^{e}$ & $0.1 \pm 0.06$ & $0.1 \pm 0.03$ & & & & & & & \\
\hline Liver $^{8}$ & $0.7 \pm 0.1$ & $0.04 \pm 0.02$ & $1.0 \pm 0.3$ & & & & & & \\
\hline Lung & $0.3 \pm 0.1$ & $0.06 \pm 0.04$ & & & & & & & \\
\hline $\begin{array}{l}\text { Rumen }^{\mathrm{h}} \\
\text { Contents }\end{array}$ & $0.06 \pm 0.007$ & $0.7 \pm 0.03$ & $<0.4$ & & & & & & \\
\hline Blood & & & & & $180 \pm 0.3$ & & & & \\
\hline Bone & & & & & & & $.0044 \pm .0041$ & $1.2 \pm 0.4$ & $16 \pm 1.8$ \\
\hline
\end{tabular}


Aqueous portion of tissue sampled.

Rumen contents from Mule deer 1 also contained ${ }^{95} \mathrm{Zr}(3.6 \pm 0.1 \mathrm{pCi} / \mathrm{g})$ and ${ }^{95} \mathrm{Nb}(0.14 \pm 0.03 \mathrm{pCi} / \mathrm{g})$.

Rumen contents from Mule deer 2 contained ${ }^{22} \mathrm{Na}(0.03 \pm 0.01)$.

Kidney contents from Mule deer 2 also contained ${ }^{203} \mathrm{Hg}(0.09 \pm 0.02 \mathrm{pCi} / \mathrm{g})$ and ${ }^{22} \mathrm{Na}(0.03 \pm 0.02 \mathrm{pCi} / \mathrm{g})$.

Muscle contents from Mule deer 2 contained ${ }^{203} \mathrm{Hg}(90.03 \pm 0.01)$.

Liver contents from Mule deer 4 also contained ${ }^{124} \mathrm{Sb}(0.08 \pm 0.04 \mathrm{pCi} / \mathrm{g})$ and ${ }^{125} \mathrm{Sb}(0.7 \pm 0.07 \mathrm{pCi} / \mathrm{g})$.

Rumen contents from Mule deer 4 also contained $124 \mathrm{Sb}(6 \pm 0.02 \mathrm{pCi} / \mathrm{g}),{ }^{125} \mathrm{Sb}(0.6 \pm 0.1 \mathrm{pCi} / \mathrm{g})$ and

${ }^{95} \mathrm{~N}(0.4 \pm 0.1)$.

Table 2. Nevada Test Site Mule Deer (Strontium-90 Concentration in Hock Bones)

\begin{tabular}{|c|c|c|c|c|c|}
\hline Kear & 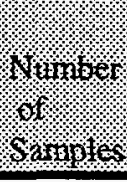 & Woringer. & 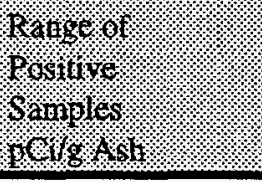 & 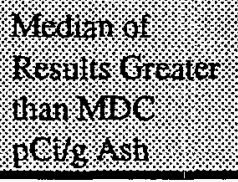 & Rerrorys \\
\hline 1982 & 2 & 2 & $1.3-1.4$ & 1.35 & \\
\hline 1983 & & & & & No Deer Collected \\
\hline 1984 & & & & & No Deer Collected \\
\hline 1985 & & & & & No Deer Collected \\
\hline 1986 & 4 & 4 & $1.2-2.8$ & 1.1 & \\
\hline 1987 & 5 & 3 & $0.5-0.7$ & 0.7 & \\
\hline 1988 & 5 & & $0.5-2.2$ & 1.2 & \\
\hline 1989 & 3 & 3 & $1.0-1.4$ & 1.2 & \\
\hline 1990 & 4 & 4 & $0.45-1.0$ & 0.92 & \\
\hline 1991 & 4 & 4 & $0.5-0.9$ & 0.7 & \\
\hline 1992 & 3 & 3 & $0.37-2.7$ & 1.0 & \\
\hline 1993 & 4 & 4 & $0.59-1.6$ & 0.85 & \\
\hline 1994 & 5 & 5 & $0.30-0.34$ & 0.32 & \\
\hline 1995 & 1 & 1 & & & \\
\hline
\end{tabular}

Note: All data in the tables is reported in 2 sigma. 
Table 3. Nevada Test Site Miscellanceous Wildlife (Strontium-90 Concentration in Bones)

\begin{tabular}{|c|c|c|c|c|c|}
\hline Yeat & Nininer. & 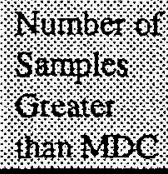 & 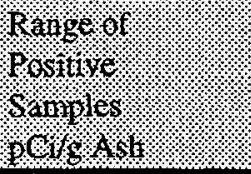 & 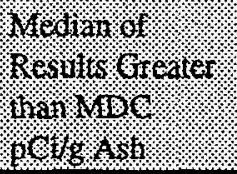 & $\mathrm{k}=1,14+\mathrm{k}$ \\
\hline 1982 & & & & & \\
\hline 1983 & & & & & \\
\hline 1984 & & & & & \\
\hline 1985 & & & & & \\
\hline 1986 & & & & & \\
\hline 1987 & 1 & 1 & 5.0 & 5.0 & Horse Bone \\
\hline 1988 & & & & & \\
\hline 1989 & 2 & 2 & $0.18-0.23$ & 0.21 & $\begin{array}{l}\text { Duck bone provided by N.D.W. to } \\
\text { check for Chernobyl Fallout }\end{array}$ \\
\hline 1990 & & & & & \\
\hline 1991 & 1 & 1 & 1.1 & 1.1 & Lion killed area 12 NTS \\
\hline 1992 & & & & & \\
\hline 1993 & 3 & 3 & $0.24-3.5$ & 2.2 & Chukar NTS \\
\hline 1994 & $\begin{array}{l}1 \\
1\end{array}$ & $\begin{array}{l}1 \\
1\end{array}$ & $\begin{array}{l}0.64 \\
0.64\end{array}$ & $\begin{array}{l}0.64 \\
0.64\end{array}$ & $\begin{array}{l}\text { Chukar NTS } \\
\text { Chukar Esmeralda Co. }\end{array}$ \\
\hline 1995 & & & & & \\
\hline
\end{tabular}

Note: All data in the tables is reported in 2 sigma. 
Table 4. Nevada Test Site Bighorn Sheep (Strontium-90 Concentration in Hock Bones)

\begin{tabular}{|c|c|c|c|c|c|}
\hline 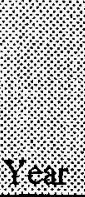 & Noniter & Wriniber & 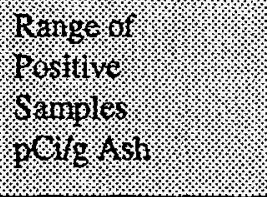 & 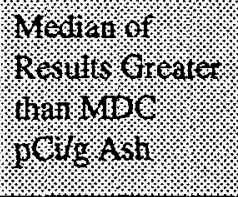 & homanto \\
\hline 1982 & 18 & 18 & $0.47-4.3$ & 1.55 & \\
\hline 1983 & 20 & 20 & $0.8-4.3$ & 1.8 & \\
\hline 1984 & 24 & 24 & $0.32-3.2$ & 1.26 & \\
\hline 1985 & 19 & 19 & $1.0-9.6$ & 2.1 & \\
\hline 1986 & 19 & 19 & $0.6-12$ & 1.6 & \\
\hline 1987 & 20 & 20 & $5.0-6.7$ & 1.8 & \\
\hline 1988 & 14 & 14 & $0.06-1.8$ & 0.9 & \\
\hline 1989 & 16 & 16 & $0.3-1.7$ & 1.1 & \\
\hline 1990 & 13 & 13 & $0.5-2.0$ & 1.4 & \\
\hline 1991 & 16 & 16 & $0.37-2.7$ & 1.0 & \\
\hline 1992 & 4 & 4 & $0.67 \cdot 1.9$ & 1.25 & \\
\hline 1993 & & & & & No Bighorn Sheep Collected \\
\hline 1994 & & & & & No Bighorn Sheep Collected \\
\hline 1995 & & & & & No Bighorn Sheep Collected \\
\hline
\end{tabular}

Note: All data in the tables is reported in 2 sigma. 
Table 5. Nevada Test Site Beef Cattle (Strontium-90 Concentration in Femur Bones)

\begin{tabular}{|c|c|c|c|c|c|}
\hline Yea & Tof lunber: & 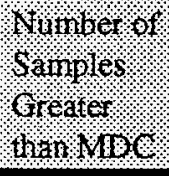 & 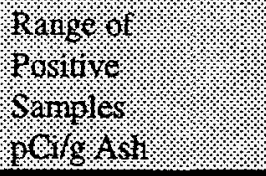 & 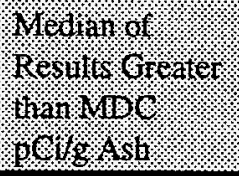 & Rerratks \\
\hline \multirow[t]{2}{*}{1982} & 4 & 4 & $0.7-1.3$ & 0.75 & Medlin's Ranch (Tikaboo Valley) (Spring) \\
\hline & 2 & 2 & $1.8-2.2$ & 2.0 & NTS (Fall) \\
\hline \multirow[t]{2}{*}{1983} & & & & & Not Sampled (Spring) \\
\hline & 4 & 4 & $0.97-1.8$ & 1.4 & Medlin's Ranch (Fall) \\
\hline \multirow[t]{2}{*}{1984} & 4 & 4 & $1.6-2.2$ & 1.6 & Nash Ranch (Hiko, NV) (Spring) \\
\hline & 4 & 4 & $1.4-1.9$ & 1.6 & Nash Ranch (Hiko, NV) (Fall) \\
\hline \multirow[t]{2}{*}{1985} & 4 & 4 & $1.6-2.2$ & 1.9 & Nash Ranch (Hiko, NV) (Spring) \\
\hline & 4 & 4 & $0.14-2.4$ & 1.2 & Wright Ranch (Hiko, NV) (Fall) \\
\hline \multirow[t]{2}{*}{1986} & 4 & 4 & $1.4-2.5$ & 2.0 & Agee Ranch (Rachel, NV) (Spring) \\
\hline & 4 & 0 & Samples lost & & Medlin's Ranch (Tikaboo Valley) (Fall) \\
\hline 1987 & $\begin{array}{l}4 \\
5\end{array}$ & $\begin{array}{l}4 \\
5\end{array}$ & $\begin{array}{l}0.33-1.0 \\
0.93-1.3\end{array}$ & $\begin{array}{l}0.57 \\
1.3\end{array}$ & $\begin{array}{l}\text { Sharp's Ranch (Nyala, NV) (Spring) } \\
\text { Medlin's Ranch (Tikaboo Valley) (Fall) }\end{array}$ \\
\hline \multirow[t]{2}{*}{1988} & 4 & 4 & $0.06-0.6$ & 0.41 & Coffer's Ranch (Beatty, NV) (Spring) \\
\hline & 4 & 4 & $0.16-0.75$ & 0.64 & Coffer's Ranch (Beatty, NV) (Fall) \\
\hline \multirow[t]{2}{*}{1989} & 3 & 3 & $0.83-1.0$ & 0.96 & Nash Ranch (Hiko, NV) (Spring) \\
\hline & 4 & 4 & $0.40-0.76$ & 0.43 & Coffer's Ranch (Beatty, NV) (Fall) \\
\hline \multirow[t]{2}{*}{1990} & 4 & 4 & $0.26-1.2$ & 0.75 & Agee Ranch (Rachel, NV) (Spring \\
\hline & 4 & 4 & $0.74-1.9$ & 1.2 & Medlin's Ranch (Tikaboo Valley) (Fall) \\
\hline \multirow[t]{2}{*}{1991} & 4 & 4 & $0.29-.99$ & 0.55 & Dahl Ranch (Delmar Valley) (Spring) \\
\hline & 4 & 4 & $0.62-2.4$ & 0.66 & Agee Ranch (Rachel, NV) (Fall) \\
\hline \multirow[t]{2}{*}{1992} & 4 & 3 & $0.44-0.75$ & 0.66 & Coffer's Ranch (Beatty, NV) (Spring) \\
\hline & 4 & 4 & $0.34-0.88$ & 0.43 & Dahl Ranch (Delmar Valley) (Spring) \\
\hline \multirow[t]{2}{*}{1993} & 4 & 4 & $0.29-0.85$ & 0.72 & Medlin's Ranch (Tikaboo' Valley) (Spring) \\
\hline & 4 & 4 & $0.93-1.6$ & 1.0 & Nash Ranch (Hiko, NV) (Fall) \\
\hline \multirow[t]{3}{*}{1994} & 4 & 3 & $0.16-0.49$ & 0.19 & Coffer's Ranch (Beatty, NV) (Spring) \\
\hline & 4 & 4 & $0.45-0.90$ & 0.67 & Sharp's Ranch (Nyala, NV) (Fall) \\
\hline & 1 & 1 & 1.4 & 1.4 & NTS Bull Area 18 (Last of NTS Bull herd) \\
\hline
\end{tabular}

Note: All data in the tables is reported in 2 sigma. 


\section{Appendix B}

Figure 1. Mountain lion sightings on the NTS.

Figure 2. Average strontium levels in bighorn sheep from 1955 - 1994.

Figure 3. Average strontium levels in cattle from $1955-1994$.

Figure 4. Average strontium levels in deer from 1955 - 1994.

Figure 5. Tritium levels in mule deer from $1982-1995$. 


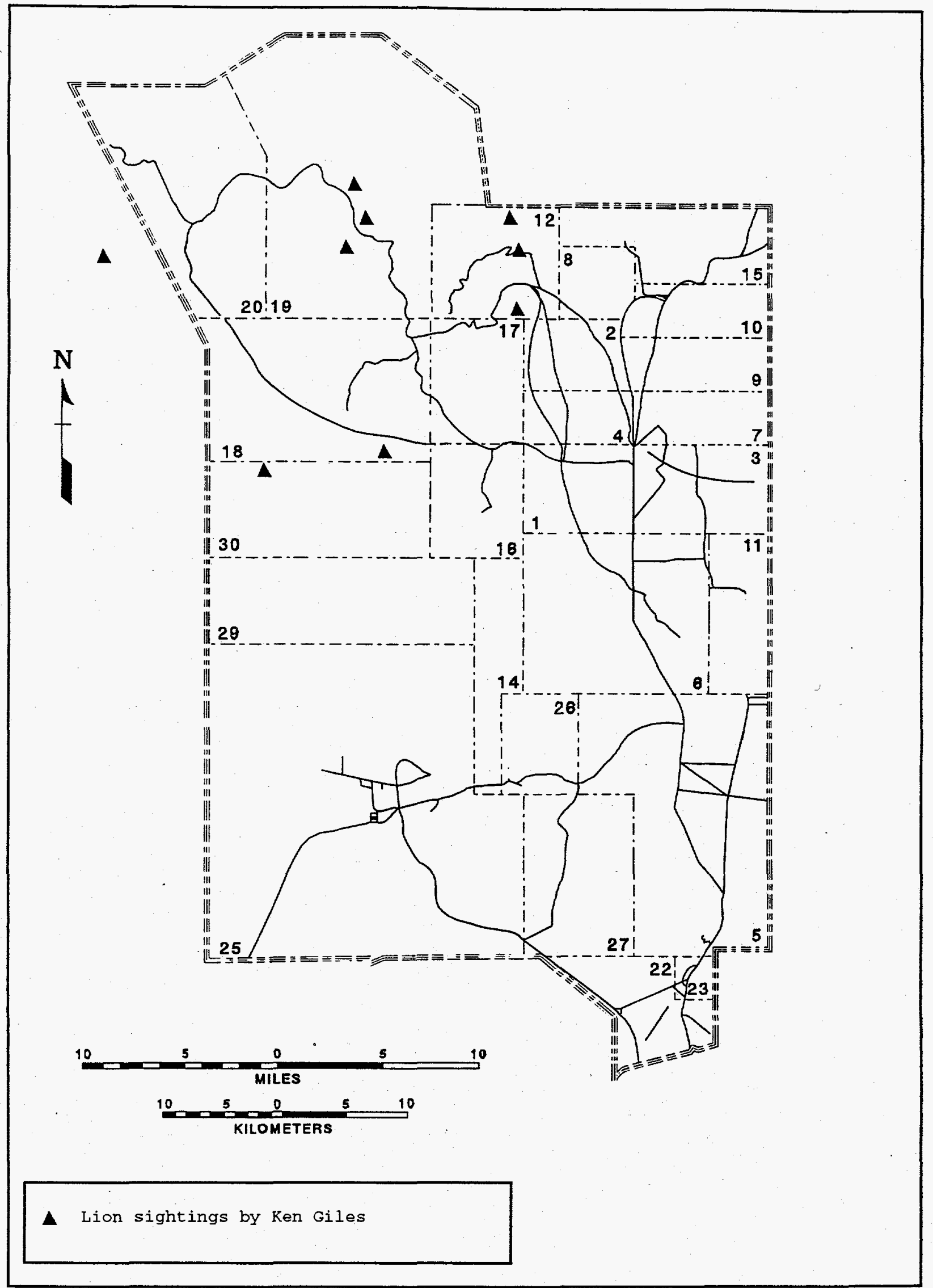

Figure 1 Mountain lion sightings on the NTS. 


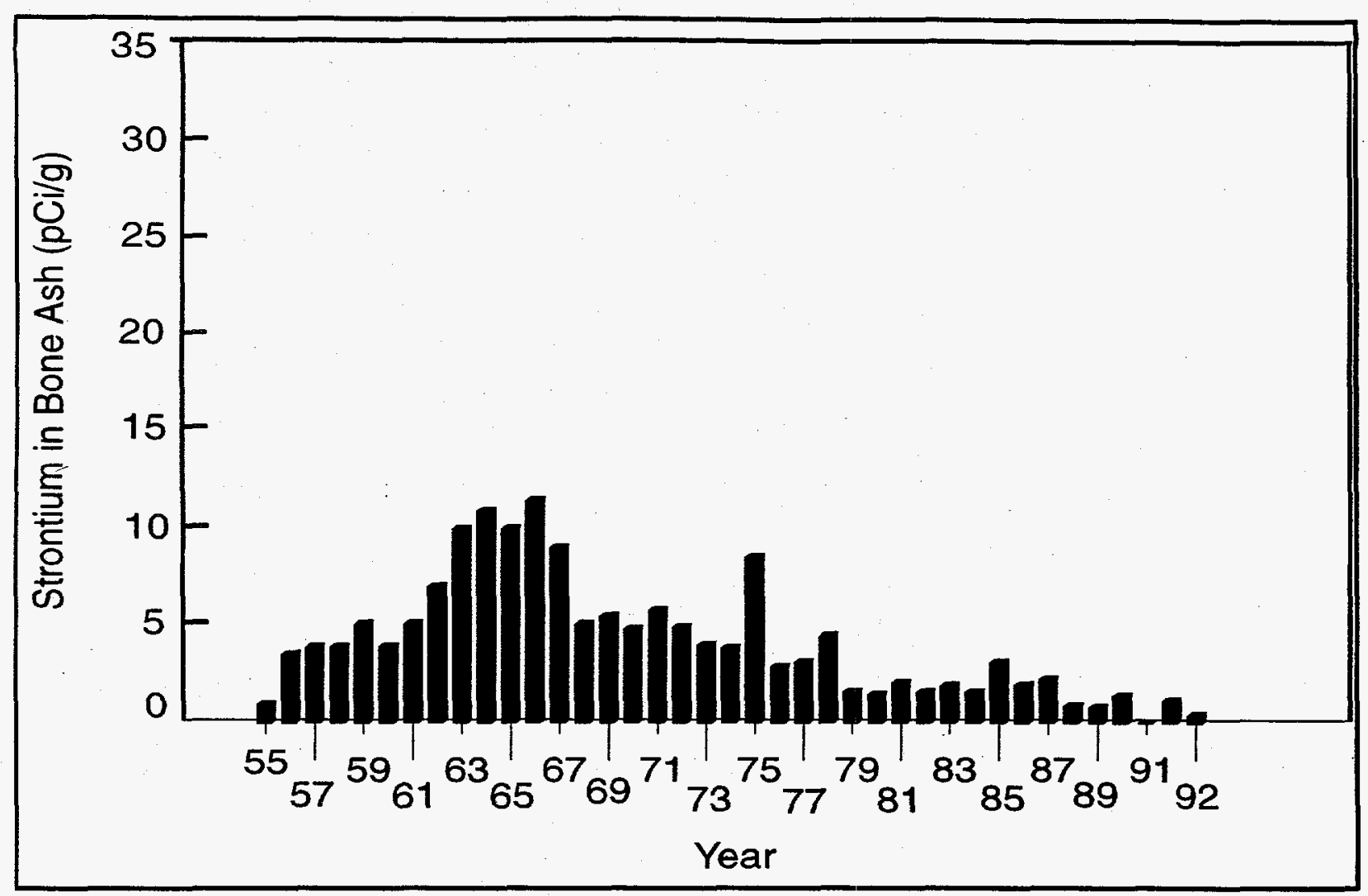

Figure 2 Average strontium-90 levels in bighorn sheep from 1955-1992.

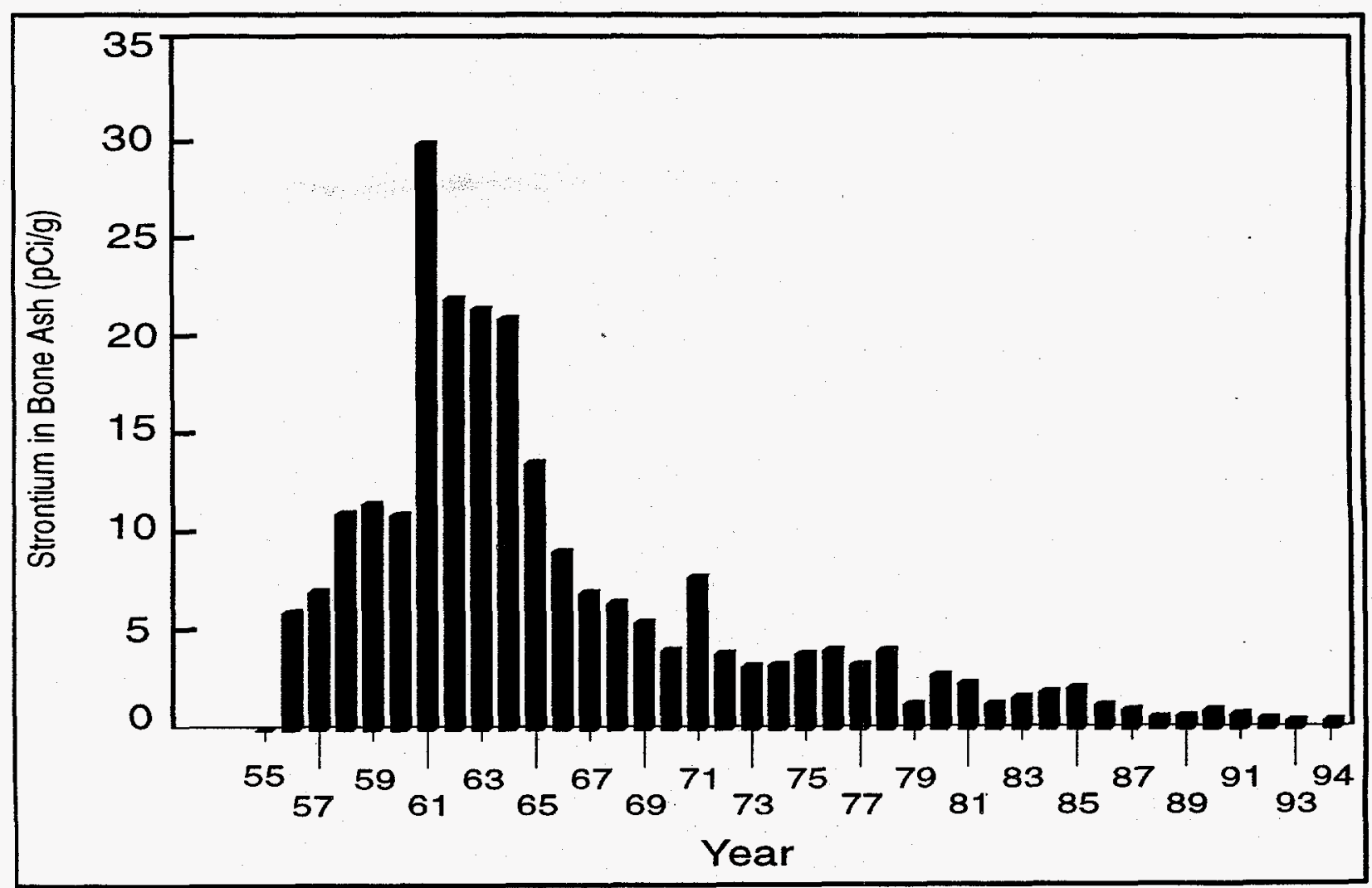

Figure 3 Average strontium-90 levels in cattle from 1955 - 1994. 


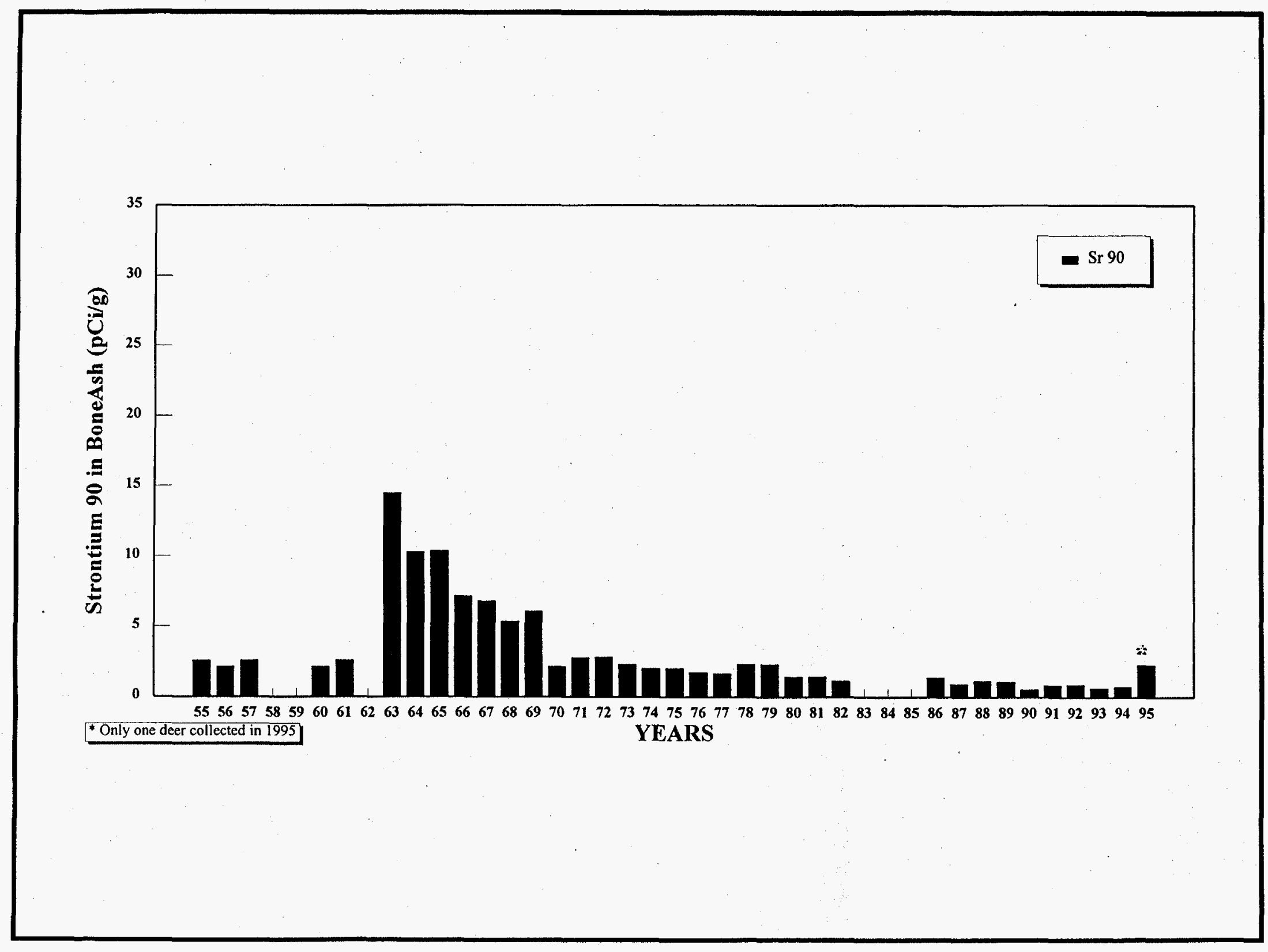

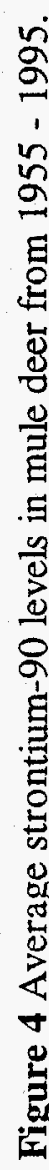




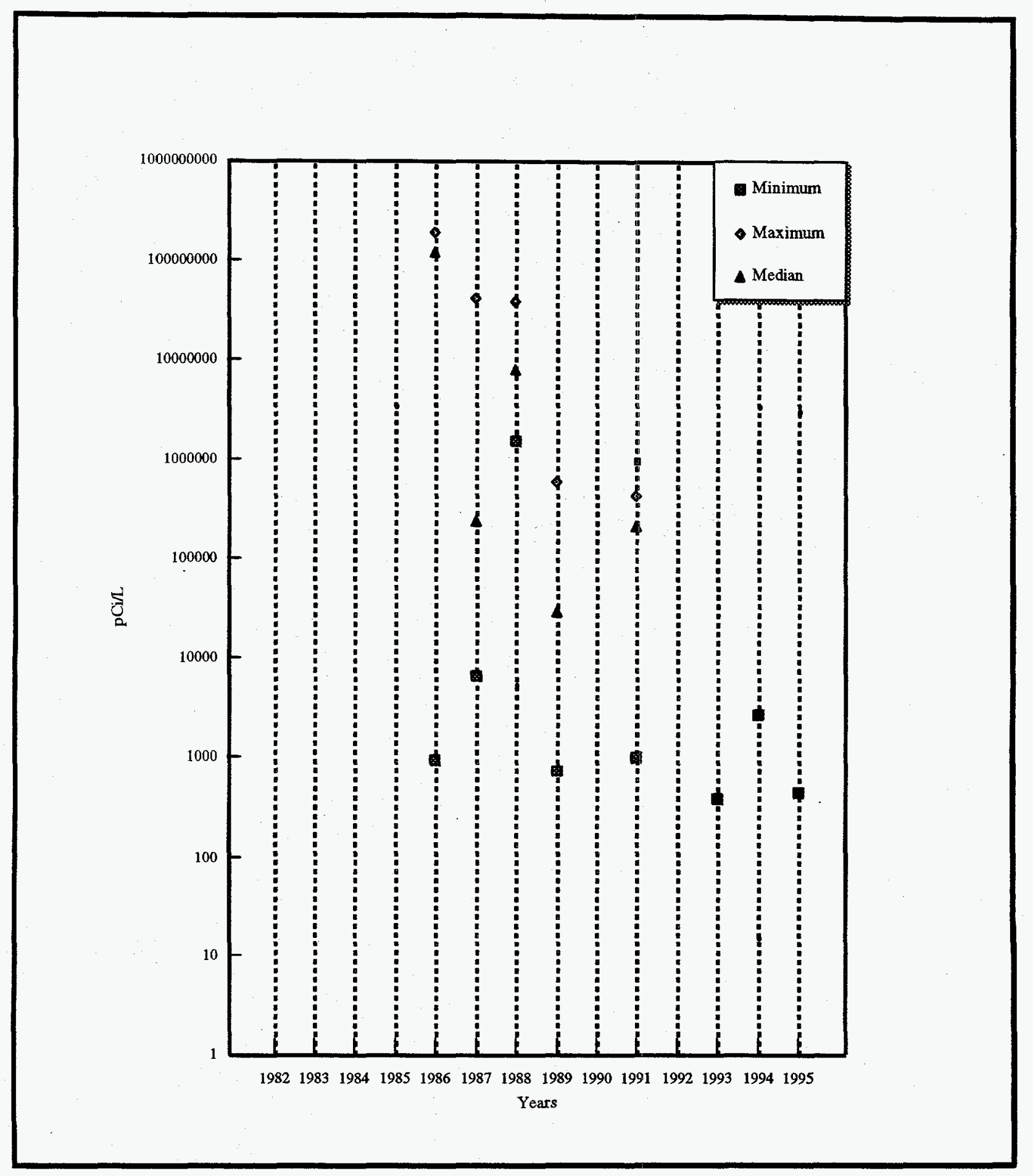

Figure 5 Tritium levels in mule deer from 1982 - 1995. 


\section{Appendix C}

\section{Announced United States Nuclear Tests}

\begin{tabular}{|c|c|c|c|}
\hline Event Name & Date & Irocation: & rumpose \\
\hline Tarko & $02 / 28 / 80$ & NTS & Weapons Related \\
\hline Norbo & $03 / 08 / 80$ & NTS & Weapons Related \\
\hline Liptauer & $04 / 03 / 80$ & NTS & Weapons Related \\
\hline Pyramid & $04 / 16 / 80$ & NTS & Weapons Related \\
\hline Colwick & $04 / 26 / 80$ & NTS & Joint US-UK \\
\hline Canfield & $05 / 02 / 80$ & NTS & Weapons Related \\
\hline Flora & $05 / 22 / 80$ & NTS & Weapons Related \\
\hline Kash & $06 / 12 / 80$ & NTS & Weapons Related \\
\hline Huron King & $06 / 24 / 80$ & NTS & Weapons Effects \\
\hline Tafi & $07 / 25 / 80$ & NTS & Weapons Related \\
\hline Verdello & $07 / 31 / 80$ & NTS & Weapons Related \\
\hline Bonarda & $09 / 25 / 80$ & NTS & Weapons Related \\
\hline Riola & $09 / 25 / 80$ & NTS & Weapons Related \\
\hline Dutchess & $10 / 24 / 80$ & NTS & Joint US-UK \\
\hline Miners Iron & $10 / 31 / 80$ & NTS & Weapons Effects \\
\hline Dauphin & $11 / 14 / 80$ & NTS & Weapons Related \\
\hline Serpa & $12 / 17 / 80$ & NTS & Joint US-UK \\
\hline Baseball & $01 / 15 / 81$ & NTS & Weapons Related \\
\hline Clairette & $02 / 05 / 81$ & NTS & Weapons Related \\
\hline Seco & $02 / 25 / 81$ & NTS & Weapons Related \\
\hline Vide & $04 / 30 / 81$ & NTS & Weapons Related \\
\hline Aligote & $05 / 29 / 81$ & NTS & Weapons Related \\
\hline Harzer & $06 / 06 / 81$ & NTS & Weapons Related \\
\hline Niza & $07 / 10 / 81$ & NTS & Weapons Related \\
\hline
\end{tabular}




\begin{tabular}{||l|l|l|l||}
\hline Pineau & $07 / 16 / 81$ & NTS & Weapons Related \\
\hline Harvarti & $08 / 05 / 81$ & NTS & Weapons Related \\
\hline Islay & $08 / 27 / 81$ & NTS & Weapons Related \\
\hline Trebbiano & $09 / 04 / 81$ & NTS & Weapons Related \\
\hline Cernada & $09 / 24 / 81$ & NTS & Weapons Related \\
\hline Paliza & $10 / 01 / 81$ & NTS & Weapons Related \\
\hline Tilci & $11 / 11 / 81$ & NTS & Weapons Related \\
\hline Rousanne & $11 / 12 / 81$ & NTS & Joint US-UK \\
\hline Akavi & $12 / 03 / 81$ & NTS & Weapons Related \\
\hline Caboc & $12 / 16 / 81$ & NTS & Weapons Related \\
\hline Jornada & $01 / 28 / 82$ & NTS & Weapons Related \\
\hline Molbo & $02 / 12 / 82$ & NTS & Weapons Related \\
\hline Hosta & $02 / 12 / 82$ & NTS & Weapons Related \\
\hline Tenaja & $04 / 17 / 82$ & NTS & Weapons Related \\
\hline Gibne & $04 / 25 / 82$ & NTS & Joint US-UK \\
\hline Kryddost & $05 / 06 / 82$ & NTS & Weapons Related \\
\hline Bouschet & $05 / 07 / 82$ & NTS & Weapons Related \\
\hline Kesti & $06 / 16 / 82$ & NTS & Weapons Related \\
\hline Nebbiolo & $06 / 24 / 82$ & NTS & Weapons Related \\
\hline Monterey & $07 / 29 / 82$ & NTS & Weapons Related \\
\hline Atrisco & $08 / 05 / 82$ & NTS & Weapons Related \\
\hline Queso & $08 / 11 / 82$ & NTS & Weapons Related \\
\hline Cerro & $09 / 02 / 82$ & NTS & Weapons Related \\
\hline Huron Landing & $09 / 23 / 82$ & NTS & Weapons Effects \\
\hline Diamond Ace & $09 / 23 / 82$ & NTS & Weapons Effects \\
\hline Frisco & $09 / 23 / 82$ & NTS & Weapons Related \\
\hline Borrego & $09 / 29 / 82$ & NTS & Weapons Related \\
\hline Seyval & $11 / 12 / 82$ & NTS & Weapons Related \\
\hline
\end{tabular}




\begin{tabular}{||l|l|l|l||}
\hline Manteca & $12 / 10 / 82$ & NTS & Weapons Related \\
\hline Coalora & $02 / 11 / 83$ & NTS & Weapons Related \\
\hline Cheedam & $02 / 17 / 83$ & NTS & Weapons Related \\
\hline Cabra & $03 / 26 / 83$ & NTS & Weapons Related \\
\hline Turquoise & $04 / 14 / 83$ & NTS & Weapons Related \\
\hline Armada & $04 / 22 / 83$ & NTS & Joint US-UK \\
\hline Crowdie & $05 / 05 / 83$ & NTS & Weapons Related \\
\hline Mini Jade & $05 / 26 / 83$ & NTS & Weapons Effects \\
\hline Fahada & $05 / 26 / 83$ & NTS & Weapons Related \\
\hline Danablu & $06 / 09 / 83$ & NTS & Weapons Related \\
\hline Laban & $08 / 03 / 83$ & NTS & Weapons Related \\
\hline Sabado & $08 / 11 / 83$ & NTS & Weapons Related \\
\hline Chancellor & $09 / 01 / 83$ & NTS & Weapons Related \\
\hline Tomme/Midnight Zephyr & $09 / 21 / 83$ & NTS & Weapons Effects \\
\hline Techado & $09 / 22 / 83$ & NTS & Weapons Related \\
\hline Romano & $12 / 16 / 83$ & NTS & Weapons Related \\
\hline Gorbea & $01 / 31 / 84$ & NTS & Weapons Related \\
\hline Midas Myth/Milagro & $02 / 15 / 84$ & NTS & Weapons Effects \\
\hline Tortugas & $03 / 01 / 84$ & NTS & Weapons Related \\
\hline Agrini & $03 / 31 / 84$ & NTS & Weapons Related \\
\hline Mundo & $05 / 01 / 84$ & NTS & Joint US-UK \\
\hline Caprock & $05 / 31 / 84$ & NTS & Weapons Related \\
\hline Duoro & $06 / 20 / 84$ & NTS & Weapons Related \\
\hline Kappeli & $07 / 25 / 84$ & NTS & Weapons Related \\
\hline Correo & $08 / 02 / 84$ & NTS & Weapons Related \\
\hline Dolcetto & $08 / 30 / 84$ & NTS & Weapons Related \\
\hline Breton & $09 / 13 / 84$ & NTS & Weapons Related \\
\hline Villita & $11 / 10 / 84$ & NTS & Weapons Related \\
\hline
\end{tabular}




\begin{tabular}{||l|l|l|l||}
\hline Egmont & $12 / 09 / 84$ & NTS & Joint US-UK \\
\hline Tierra & $12 / 15 / 84$ & NTS & Weapons Related \\
\hline Vaughn & $03 / 15 / 85$ & NTS & Weapons Related \\
\hline Cottage & $03 / 23 / 85$ & NTS & Weapons Related \\
\hline Hermosa & $04 / 02 / 85$ & NTS & Weapons Related \\
\hline Misty Rain & $04 / 06 / 85$ & NTS & Weapons Effects \\
\hline Towanda & $05 / 02 / 85$ & NTS & Weapons Related \\
\hline Salut & $06 / 12 / 85$ & NTS & Weapons Related \\
\hline Ville & $06 / 12 / 85$ & NTS & Weapons Related \\
\hline Maribo & $06 / 26 / 85$ & NTS & Weapons Related \\
\hline Serena & $07 / 25 / 85$ & NTS & Weapons Related \\
\hline Chamita & $08 / 17 / 85$ & NTS & Weapons Related \\
\hline Ponil & $09 / 27 / 85$ & NTS & Weapons Related \\
\hline Mill Yard & $10 / 09 / 85$ & NTS & Weapons Effects \\
\hline Diamond Beech & $10 / 09 / 85$ & NTS & Weapons Effects \\
\hline Roquefort & $10 / 16 / 85$ & NTS & Weapons Related \\
\hline Kinibito & $12 / 05 / 85$ & NTS & Joint US-UK \\
\hline Goldstone & $12 / 28 / 85$ & NTS & Weapons Related \\
\hline Glencoe & $03 / 22 / 86$ & NTS & Weapons Related \\
\hline Mighty Oak & $04 / 10 / 86$ & NTS & Weapons Effects \\
\hline Jefferson & $04 / 22 / 86$ & NTS & Weapons Related \\
\hline Panamint & $05 / 21 / 86$ & NTS & Weapons Related \\
\hline Tajo & $06 / 05 / 86$ & NTS & Weapons Related \\
\hline Darwin & $06 / 25 / 86$ & NTS & Joint US-UK \\
\hline Cybar & $07 / 17 / 86$ & NTS & Weapons Related \\
\hline Cornucopia & $07 / 24 / 86$ & NTS & Weapons Related \\
\hline Aleman & $09 / 11 / 86$ & NTS & Weapons Related \\
\hline Labquark & NTS & Weapons Related \\
\hline
\end{tabular}




\begin{tabular}{||l|l|l|l||}
\hline Belmont & $10 / 16 / 86$ & NTS & Weapons Related \\
\hline Gascon & $11 / 14 / 86$ & NTS & Weapons Related \\
\hline Bodie & $12 / 13 / 86$ & NTS & Weapons Related \\
\hline Hazebrook & $02 / 03 / 87$ & NTS & Weapons Related \\
\hline Tornero & $02 / 11 / 87$ & NTS & Weapons Related \\
\hline Middle Note & $03 / 18 / 87$ & NTS & Weapons Effects \\
\hline Delamar & $04 / 18 / 87$ & NTS & Weapons Related \\
\hline Presidio & $04 / 22 / 87$ & NTS & Weapons Related \\
\hline Hardin & $04 / 30 / 87$ & NTS & Weapons Related \\
\hline Brie & $06 / 18 / 87$ & NTS & Weapons Related \\
\hline Mission Ghost & $06 / 20 / 87$ & NTS & Weapons Effects \\
\hline Panchuela & $06 / 30 / 87$ & NTS & Weapons Related \\
\hline Midland & $07 / 16 / 87$ & NTS & Joint US-UK \\
\hline Tahoka & $08 / 13 / 87$ & NTS & Weapons Related \\
\hline Lockney & $09 / 24 / 87$ & NTS & Weapons Related \\
\hline Borate & $10 / 23 / 87$ & NTS & Weapons Related \\
\hline Waco & $12 / 01 / 87$ & NTS & Weapons Related \\
\hline Mission Cyber & $12 / 02 / 87$ & NTS & Weapons Effects \\
\hline Kernville & $02 / 15 / 88$ & NTS & Weapons Related \\
\hline Abilene & $04 / 07 / 88$ & NTS & Weapons Related \\
\hline Schellbourne & $05 / 13 / 88$ & NTS & Weapons Related \\
\hline Laredo & $05 / 21 / 88$ & NTS & Weapons Related \\
\hline Comstock & $06 / 02 / 88$ & NTS & Weapons Related \\
\hline Rhyolite & $06 / 22 / 88$ & NTS & Weapons Related \\
\hline Nightingale & $06 / 22 / 88$ & NTS & Safety Experiment \\
\hline Alamo & $07 / 07 / 88$ & NTS & Weapons Related \\
\hline Kearsarge & $08 / 17 / 88$ & NTS & Weapons Related \\
\hline Bullfrog & NTS & Weapons Related \\
\hline
\end{tabular}




\begin{tabular}{|l|l|l|l||}
\hline Dahlhart & $10 / 13 / 88$ & NTS & Weapons Related \\
\hline Misty Echo & $12 / 10 / 88$ & NTS & Weapons Effects \\
\hline Texarkana & $02 / 10 / 89$ & NTS & Weapons Related \\
\hline Kawich & $02 / 24 / 89$ & NTS & Weapons Related \\
\hline Ingot & $03 / 09 / 89$ & NTS & Weapons Related \\
\hline Palisade & $05 / 15 / 89$ & NTS & Weapons Related \\
\hline Tulia & $05 / 26 / 89$ & NTS & Weapons Related \\
\hline Contact & $06 / 22 / 89$ & NTS & Weapons Related \\
\hline Amarillo & $06 / 27 / 89$ & NTS & Weapons Related \\
\hline Disko Elm & $09 / 14 / 89$ & NTS & Weapons Effects \\
\hline Hornitos & $10 / 31 / 89$ & NTS & Weapons Related \\
\hline Muleshoe & $11 / 15 / 89$ & NTS & Weapons Related \\
\hline Barnwell & $12 / 08 / 89$ & NTS & Joint US-UK \\
\hline Whiteface & $12 / 20 / 89$ & NTS & Weapons Related \\
\hline Metropolis & $03 / 10 / 90$ & NTS & Weapons Related \\
\hline Bullion & $06 / 13 / 90$ & NTS & Weapons Related \\
\hline Austin & $06 / 21 / 90$ & NTS & Weapons Related \\
\hline Mineral Quarry & $07 / 25 / 90$ & NTS & Weapons Effects \\
\hline Sundown & $09 / 20 / 90$ & NTS & Weapons Related \\
\hline Ledoux & $09 / 27 / 90$ & NTS & Weapons Effects \\
\hline Tenabo & $10 / 12 / 90$ & NTS & Weapons Related \\
\hline Houston & $11 / 14 / 90$ & NTS & Joint US-UK \\
\hline Coso & $03 / 08 / 91$ & NTS & Weapons Related \\
\hline Bexar & $04 / 04 / 91$ & NTS & Weapons Related \\
\hline Montello & $04 / 16 / 91$ & NTS & Weapons Related \\
\hline Floydada & $08 / 15 / 91$ & NTS & Weapons Related \\
\hline Hoya & $09 / 14 / 91$ & NTS & Weapons Related \\
\hline Distant Zenith & $09 / 19 / 91$ & NTS & Weapons Effects \\
\hline
\end{tabular}




\begin{tabular}{||l|l|l|l||}
\hline Lubbock & $10 / 18 / 91$ & NTS & Weapons Related \\
\hline Bristol & $11 / 26 / 91$ & NTS & Weapons Related \\
\hline Junction & $03 / 26 / 92$ & NTS & Joint US-UK \\
\hline Diamond Fortune & $04 / 30 / 92$ & NTS & Weapons Effects \\
\hline Victoria & $06 / 19 / 92$ & NTS & Weapons Related \\
\hline Galena & $06 / 23 / 92$ & NTS & Weapons Related \\
\hline Hunters Trophy & $09 / 18 / 92$ & NTS & Weapons Effects \\
\hline Divider & $09 / 23 / 92$ & NTS & Weapons Related \\
\hline & & & \\
\hline & & & \\
\hline
\end{tabular}

